\section{Arsimmer McCoy}

Arsimmer McCoy is a 34-year-old poet, storyteller, \& Speaker, and the mother to a righteous 10-year old girl child. Born in Baptist Hospital, raised in Richmond Heights, Fl. Arsimmer earned her Bachelor's degree of Arts and literature at the historic Florida Memorial University. Arsimmer gives thanks, for being able to produce work in the form of poetry, short story literature, performance workshops, and creative direction, for over twelve years. McCoy resides in Miami Gardens, Fl which

she will still refer to until the day she dies, as Carol City.

\section{Down By The Riverside}

"Gonna lay down my burden Down by the riverside Gonna lay down my burden

Gather your grit.

Remember your training.
Stand steady on the balls of you

feet,

then wait.
This is the moment.

We have rivaled with these interlopers

for centuries.

We ve agreed to meer
at the water's edge.

Bring The women in to perform the ritual.

Rub bergamot on the daughter's temples.

Ground Geraniums into our

Place lavender flowers and eucalyptus into the $h$

Page 4

Root Work Journal

Vol- 1 Issue- 2
Push nickels into the navels of the children

After the death of our sweet King

the elders say we lost our audacily,

and replace it with reasoning.

Forgetting our training.

They took our babies and hung

Drugged us and left our girls

Sputtering to ghosts on the streets.

Split open our veins and let then

leak.

Just to see how we bleed.

And they saw magic

Since then, they have been seeking to end us.

Our survival means their demise.

Now is the time.

Remember your training.

When your mother took you
out to look at the stars and

told you to follow the gourd.

When the pipes froze in the walls,

your uncle wrapped you in sheepskin,

rubbed your driced skin with petroleum,

The black smoke.

rollin round in puke and shii.

Threw our Kuba overskirts overboard;

The goats blood from the rite of passag

Hadn't even dried yet on our fle

to call on them.

When yemoja troubled the watwers

she heaved and pushed.

Nurky Tsunamis drew back and rolled.

There was an eclipse of that same

spread their wings, and
kicked up red dust.

When the current comes,

it will take us first.

We the children of Yemoja

Hhen you pis yc

on us, to drown us,

back up to the surface

aughte

We been wading through rivers

And this land was all river once befor

and it will be

Our ancestors sit on the bottom

of the ocean floor waiting.

Its them whispering,

Remember your training.

When you separate a people.

destroy their culture,

and never atone for it,

and they still find a way to come togethe

it is dangerous.

So I say remember Stono,

Chekika and the seminoles.

Remember Turner

And the Gold coast warriors.

Soldiers who never forgot who they were

and sang to the sun

with nooses on their

At the public execution in New York.

It began in the water
It will end in the sea

Fish children,

Remember your training.

Now take to the water

and let peace be still. 